\title{
ECONOMIC ANALYSIS OF SMALLHOLDER MAIZE FARMERS: IMPLICATIONS FOR PUBLIC EXTENSION SERVICES IN EASTERN CAPE
}

\author{
Agbugba, I. K. ${ }^{1}$, Christian, $\mathrm{M.}^{2}$ and Obi, A. ${ }^{3}$ \\ Correspondence author: M. Christian. Email: $33369623 @$ nwu.ac.za
}

\section{ABSTRACT}

This study sought to determine the economics of maize farmers in Amatole District, Eastern Cape. Multistage sampling procedure was used to select hundred and nine (109) smallholder farmers (homestead and irrigators). Descriptive statistics and gross margin analysis were used to determine the economics and profitability of maize in the study area. Findings indicated that majority (66 per cent) of them were men with an average age of 61 years old, majority (69 per cent) were married, with mean household size of 4 persons and household heads having some primary education. Moreover, majority (76 per cent) of the farmers depended on irrigation technology; majority (33 per cent) of the famers spent between 9 and 11 years of experience in farming; majority (89 per cent) of the respondents in the study area were dependent on farming as their major occupation and livelihood. Pertaining to land acquisition, majority (48\%) of the farmers believed that the traditional or community leaders set rules and regulations regarding land acquisition. From the profitability analysis, smallholder farmer irrigators generated significantly higher yield, total revenues and gross margins more than the homestead gardeners at 5, 10 and 5 per cent levels, respectively. Moreover, homestead gardeners spent more money in purchase of inputs and this may have contributed to their low gross margins. On the other hand, smallholder-farmer irrigators who incur less input costs have higher chances of benefiting from price discounts and transport offer by input suppliers than the homestead gardeners. This results in smallholder farmer irrigators wielding more profits, thereby creating more income and wealth which is pivotal in the improvement of farmers' livelihoods.

Keywords: Economics, profitability, Maize farmers, Extension service, Eastern Cape.

\section{INTRODUCTION}

\subsection{Background}

With the increase in South Africa's productivity level of smallholder farmers, general food production for households and small surpluses, attention is raised in line with improving of the socio-economic status of the farmers who are directly or indirectly engaged in food production and distribution in villages and district markets, respectively (Hagos and Geta, 2016). Sometimes, smallholder farmers are compelled to deliver their produce to the markets, usually

\footnotetext{
1 Professor, Department of Agricultural and Applied Economics, Rivers State University, PMB 5080, Port Harcourt, Nigeria ; E mail: iykeagbugba1@gmail.com

${ }^{2}$ Senior Lecturer/Researcher at the North West University: Agricultural Economics and Extension, P/Bag x 2046, Mmabatho, 2735. Tel. 018389 2786; E mail: mzuyanda1990@ gmail.com, ORCID: 0000-0003-4446-0298

${ }^{3}$ Professor of Agricultural Economics, Department of Agricultural Economics \& Extension, University of Fort Hare, Private Bag X1314, Alice 5700 South Africa. Email: aobi@ufh.ac.za.
} 
through imposition of a quota to be supplied to a state agency, since their contribution and significant role to the economy is becoming significant (Madzivhandila et al. 2016).

The exceptional role played by smallholder farmers in developing Africa's agriculture, brings about high economic interest and indeed raises additional incomes at the farm or famer level, all things remaining equal (Ezihe et al. 2017). According to Sinyolo et al. (2014), smallholder agriculture and rural development play a significant role in reducing poverty and unemployment. In order words, enhancing the farmers' roles led to the government adopting a variety of initiatives in developing smallholder agriculture. This involved placing extension officers in the wards for onward implementation of government programmes, land reform programmes thereby forming new water rights legislation (Offiah, 2015; AgriSA, 2017).

At this point, it has become pertinent to define agriculture in the South African context. Agriculture, according to Von Loeper et al. (2016) comprises of two (2) farmer-categories which are the subsistent farmers in the former homeland areas and the large-scale commercial (mainly white) farmers. However, this is in contrast with the situation in many other countries of the world, where one would find a whole range of farm sizes, ranging from the very small or subsistence farmer to the very large farmer/agribusinesses (Ibeawuchi et al. 2015). There is therefore, a strong consensus that agriculture offers a huge investment opportunity and is essential for development across the South African region (Department for International Development, 2015; Alliance for a Green Revolution in Africa, 2017).

According to Wiggins and Keats (2013), subsistent or smallholder farmers who commercialize their production and marketing activities may be the central vehicle to agricultural development and could be seen as the vital tool for economy wide growth and development in South Africa. Hardaker (2015) from his studies on the structural transformation of agriculture made a similar observation that smallholder agricultural enterprise is the only way to agricultural development. According to South African Government (2015) maize is described as the most dominant crop grown, marketed and consumed in South Africa. Researches have shown that South Africa's role in the exportation of maize in relation to other countries of Africa is paramount and with its importance not over emphasized (Beinart, 2018).

According to DAFF (2018), the total production level of maize was generally erratic between 2005 and 2009, with more stable levels between 2002 and 2004. In 2007, South Africa moved from being a net importer of maize to assuming a net exporter-role in 2009. The maize industry is becoming increasingly important and thus, currently an important earner of foreign exchange through the export of maize and maize products (Macauley, 2015). Maize is the largest locally produced field crop, and the most important source of carbohydrates in the southern African region (AgriSA 2017). It is pertinent to note that amongst the areas devoted to farmlands for crop agriculture in South Africa, the farming area or land where maize crop was planted ranked the highest, followed by wheat and, to a lesser extent, sugarcane and sunflowers (SACCG, 2017).

According to DAFF (2018) more than 9,000 commercial maize producers are responsible for the major part of the South African crop, while the rest is produced by thousands of smallholder farmers. Since maize is the dominant staple crop in South Africa, it could have substantial positive impacts on the livelihoods and food security of smallholder farmers (Zuma et al. 2018). Moreover, apart from being the most important grain crop in South Africa, it is produced 
throughout the country under diverse environments (Beinart, 2018). It is described as a cereal crop from the family Graminea and botanical name, Zea mays L (Macauley, 2015). Research shows that amongst the major cereals grown in South Africa, Maize is the highest in its nutritional water productivity in energy with $3856 \mathrm{kcal} / \mathrm{m}^{3}$ and $16195 \mathrm{KJ} / \mathrm{m}^{3}$ and in protein with $77 \mathrm{~g} / \mathrm{m}^{3}$ (Zuma et al., 2018).

For instance, in the Eastern Cape (EC) province of South Africa, maize is the most important summer crop in the smallholder farming areas (Muzangwa, 2017). Its productivity is very low with average yields of less than 1 tonne $\mathrm{ha}^{-1}$. Low and variable rainfall is a major limiting factor to maize production. The soils in the EC are also inherently infertile, shallow and are prone to crusting (Hemming, 2016). However, improved open pollinated varieties (OPVs) from CIMMYT are under evaluation in the EC. Preliminary research results have shown that these varieties perform better compared with some local checks. However, their response to the different plant populations and nitrogen fertilizer rates has not been ascertained under the variable agro-ecological conditions of the EC (Sibanda et al. 2016). As a matter of fact, it is sufficiently critical to improve maize productivity level for smallholder farmers as this will in turn determine the level of profits they will wield.

On the other hand, one of the most challenging socio-economic problems currently facing smallholder maize farming in South Africa is their inability in establishing viable rural livelihoods (Von Loeper et al., 2016). There is indeed ample international evidence that smallholder maize farming has great potentials in generating employment and income opportunities for the rural farmers. More so, it is argued that smallholder maize farmers are potentially competent in certain activities with pro-active policy support from government (Singh et al., 2016). However, these opportunities could be developed into "viable niches" for future smallholder maize famers. The challenge with maize farming in South Africa is to remove the structural constraints such as that inhibit the growth of a vibrant commercial smallholder sector (DAFF, 2018). Such problems include lack of market, poor storage and poor packaging of the produce and product for market sales, and could lead to high economic losses which could invariably affect the profitability, as well as the livelihood status of the farmers.

\subsection{Objectives of the Study}

The general objective of the study is to examine the economic analysis of smallholder maize farmers in Eastern Cape Province of South Africa. Specifically, the study endeavoured to analyse the socio-economic features of the smallholder maize farmers; analysed their profitability status in line with their costs and returns implication, as well as comparing the smallholder irrigators and homestead gardeners in the study area.

\section{CONCEPTUAL AND THEORETICAL FRAMEWORK}

The framework represents how different factors inter-relate to influence maize productivity, profitability ultimately the welfare of maize farmers. The policy environment is characterized by the existing political and economic factors in the country which have an influence on the farming system. Production factors such as seeds, fertilizers, land size and pesticides are essential for maize production. Therefore, the availability and distribution of these inputs may be influenced by the policy framework in place, which in turn determines the extent of maize profitability. 
Maize productivity on the other hand is also affected by the farm profit efficiency. This is supported by the notion that for a production process to be effective, the manner in which available farm resources are utilized is crucial. But the farms profit efficiency is also influenced by institutional and socio-economic characteristics of a farmer. Institutional factors include access to the market, group membership, credit access and access to extension services. Socioeconomic characteristic such as age is assumed to have a negative influence on profitability. This is because, older farmers tend to be risk averse and as such they tend to be late adopters of technology.

\section{METHODOLOGY}

\subsection{Description of the study area}

The study was conducted in Eastern Cape Province (ECP) of South Africa. The ECP is one of the nine provinces of South Africa, bordering with the provinces of the Western Cape, the Free State, KwaZulu-Natal and Lesotho in the north (Eastern Cape Department of Rural Development and Agrarian Reform 2011). The area is made up of thirty-nine (39) municipalities of which thirty-seven (37) and two (2) are categorized as local and metropolitan municipalities, respectively. The area is referred to as the traditional home of the Xhosa tribal group of South Africa. The vast interior of the Province ranges from the dry Karoo in the west to the rolling hills and cascading rivers of the Transkei in the East. It is made up of two regions: The Western and the Eastern regions. The area lies within latitudes and longitudes $32^{\circ} 00^{\prime}$ South and $26^{\circ} 00^{\prime}$ East (Map of the World 2014). The ECP has a land area covering approximately 169,580 square kilometres, which is about13.9 per cent of the South African total area (Brand South Africa 2017). Out of the 51, 770, 560 persons which make up South Africa's total population, the area is estimated to have 6,562,053 persons (AgriSA, 2017). In order words, the population of people living in the rural area accounted for 60 per cent of the total population. The demographic features of ECP is characterized by high level of illiteracy, high level of poverty, high unemployment rate, poor infrastructural facilities and lack of other basic amenities. According to SACCG (2017), the contribution of agriculture to the GDP of the area has been on the decline. Due to the nature of the study, some purposive and random sampling techniques were adopted for the study. Information regarding the operational status of the irrigation schemes in the ECP of South Africa was accessed through stakeholder meetings with the officials of the Department of Rural Development and Agrarian Reform (DRDAR), and officials at the Municipal offices, as well as the community members. Based on the information gathered, the two smallholder irrigation schemes and the surrounding communities were identified. Out of the thirty-seven (37) municipalities that make up the ECP of South Africa, two (2) municipalities namely: Qamata and Tyefu irrigation schemes were purposively chosen because they are considered the largest small-scale irrigation schemes in the Transkei and Ciskei homelands, respectively. A research team involved in data collection who sought support from extension officers and were assisted by community authorities. A random selection technique was adopted in selecting thirty (30) homestead maize gardeners and forty (40) smallholder maize irrigators in Qamata area, while four (4) homestead maize gardeners and thirty-five (35) smallholder maize irrigators in Tyefu area, respectively. This resulted in a total of 70 farmers being interviewed in Qamata and 39 farmers in Tyefu irrigation schemes, respectively. In all, an overall sample size of 109 smallholder maize farmers was selected for the study. 


\subsection{Analytical Techniques}

\subsubsection{Demographic and socio-economic characteristics}

Descriptive statistics such as frequencies and percentages were used to describe the socioeconomic features of the smallholder maize farmers in the study area.

\subsubsection{Gross margin analysis}

Gross margin serves as the unit of analysis in determining the profitability of smallholder maize enterprises in line with their costs and returns implication, as well as comparing them in line with their smallholder irrigators and homestead maize gardeners. Gross margins are generally quoted per unit of the most limiting resource. For this study, gross margin is simply an estimate or a budget of the income and costs associated with the smallholder maize enterprise. Gross margin analysis (GMA) was used to determine the class of smallholder maize farmers (irrigators or gardeners) are more profitable and is expressed in Rands/ha. A gross margin is calculated using the following formula:

$\mathrm{GM}=\mathrm{TR}-\mathrm{TPC}$

Where, GM is gross margin in Rands per hectare for the smallholder maize enterprise; TR is total revenue in Rands per hectare; TPC is the total production cost in Rands per hectare.

\section{RESULTS AND DISCUSSION}

\subsection{Socio-economic Features of Smallholder Maize Farmers}

The socio-economic features of the respondents in this study included gender, age, marital status, household size, level of education, distribution of farmers according to irrigation scheme, occupation and number of years spent in smallholder maize enterprise.

\subsubsection{Gender Distribution of the Household Head}

Gender is said to determine to a great extent farmers' involvement in irrigation practices which they engage in. This is because such agribusiness practices are gender specific. This is the reason why data was collected on gender of the units interviewed and presented in Table 1.

Table 1: Distribution of the respondents according to gender

\begin{tabular}{|l|c|c|c|c|}
\hline Sex & Frequency & Percentage & Valid Percent & Cumulative \\
\hline Male & 72 & 66.1 & 66.1 & 66.1 \\
\hline Female & 37 & 33.9 & 33.9 & 100.0 \\
\hline Total & 109 & 100.0 & 100.0 & 166.1 \\
\hline
\end{tabular}

Source: Field Survey Data, 2014.

Table 1 shows the relationships between the genders. From the table, it could be deduced that there are more male compare with female with the $72 \%$ out of the totality of the sample being men, $37 \%$ is for female of part of the total number interviewed. This agrees with the study of Kodua-Agyekum (2009) that more dry agricultural lands were allocated to males as a result of their bias of their African rules and norms. 


\subsubsection{Age Distribution of the Household Heads}

Age is an important factor in diverse agricultural enterprises, and most socio-economic studies have shown that age is inversely related to performance (Agbugba, Nweze, Achike and Obi, 2013). In due course, data was collected on the age distribution of the farmers interviewed. Therefore, the results were presented in Table 2.

Table 2: Distribution of the respondents according to age

\begin{tabular}{|l|l|l|l|l|}
\hline Age & Frequency & \multicolumn{1}{|c|}{ Percentage } & Valid Percent & Cumulative \\
\hline $35-40$ & 18 & 16.51 & 16.51 & 16.51 \\
\hline $41-45$ & 9 & 8.26 & 8.26 & 24.77 \\
\hline $46-50$ & 14 & 12.85 & 12.85 & 37.62 \\
\hline $51-55$ & 22 & 20.18 & 20.18 & 57.8 \\
\hline $56-60$ & 9 & 8.26 & 8.26 & 66.06 \\
\hline $61-65$ & 35 & 32.11 & 32.11 & 98.17 \\
\hline $66-70$ & 2 & 1.83 & 1.83 & 100.0 \\
\hline Total & 109 & 100.0 & 100.0 & \\
\hline
\end{tabular}

Source: Field Survey Data, 2014

Results from Table 2 shows that the average age of the household head among smallholder irrigator and homestead food gardeners is about 61 years, this implies that both the irrigation schemes at Qamata and Tyefu might be operating under less productive status due to their age which is considered to be weak compared to youthful age which seems to be more productive (Ogundele and Okoruwa, 2006). Most of the youth in the area may not be interested in farming work thus, left the area in search of more paying employment (Obi and Pote, 2012) for a white collared job, thereby creating a gap.

\subsubsection{Marital Status Distribution of the Household Heads}

Marital status is a crucial factor in the farming profession. A high proportion of married respondents suggest an additional supply of labour from the family (Ezihe, Agbugba and Iornum, 2014). In view of this study, data was collected on the marital status of smallholder maize farmers, and Table 2 presented the results.

Table 3: Distribution of the respondents according to marital status

\begin{tabular}{|l|l|l|l|c|}
\hline Marital Status & Frequency & \multicolumn{1}{|c|}{ Percent } & Valid Percent & Cumulative Percent \\
\hline Married & 75 & 68.81 & 68.81 & 68.81 \\
\hline Single & 5 & 4.58 & 4.58 & 73.39 \\
\hline Divorced & 14 & 6.42 & 6.42 & 79.81 \\
\hline Widow & 19 & 17.44 & 17.44 & 97.25 \\
\hline Widower & 3 & 2.75 & 2.75 & 100.0 \\
\hline Total & 109 & 100.0 & 100.0 & \\
\hline
\end{tabular}

Source: Field Survey Data, 2014

From Table 3, the marital status of farmers is an important element in farming enterprise. Therefore, its importance is prominent as farming households takes its advantage of large families in providing family labour. The results indicated that majority (69\%) of the 
respondents are married, $6 \%$ divorced, $5 \%$ are single while the rest $(20 \%)$ of the respondents are widowed.

\subsubsection{Household Size Distribution of the Farmers}

Household size has a very important bearing with business and income (Enete and Agbugba, 2008). This was the reason why data was collected on household size. The results of the distribution of the farmers according to their household sizes are presented in Table 4.

Table 4: Distribution of the respondents according to household size

\begin{tabular}{|c|l|l|l|}
\hline Household Size & \multicolumn{1}{|c|}{ Frequency } & Percentage & \multicolumn{1}{c|}{ Cumulative } \\
\hline $1-4$ & 60 & 55.05 & 55.05 \\
\hline $5-6$ & 36 & 33.03 & 88.08 \\
\hline $7-9$ & 11 & 10.09 & 98.17 \\
\hline $10-$ Above & 2 & 1.83 & 100 \\
\hline Total & 109 & 100 & \\
\hline
\end{tabular}

Source: Field Survey Data, 2014

Similarly, Table 4 indicated that the household sizes of the respondents engaged family members in farming. However, in this case, a family with 4 members has the highest frequency distribution (55\%). Households with 5-6 persons have $33 \%$ of the total respondents, while $2 \%$ of the population has family size greater than 10 persons. In essence, the use of family labour helped reduce the cost that would have been spent on hired labour.

The implication of this is that more cost will be incurred due to more hired labour employed to supplement the family labour (Ezihe et al., 2014).

\subsubsection{Distribution of Maize Farmers according to their Educational Level}

Education is a vital force to reckon with in effective farming household performance and could inform on how best a new technology is adopted. Data was collected from the maize farmers interviewed on their level of education and the results presented in Table 5.

Table 5: Distribution of the respondents according to level of educational

\begin{tabular}{|l|l|l|l|l|}
\hline Educational Level & Frequency & Percent & Valid Percent & Cum. Percent \\
\hline No education & 52 & 47.71 & 47.71 & 47.71 \\
\hline Primary education & 32 & 29.36 & 29.36 & 77.07 \\
\hline Secondary education & 23 & 21.10 & 21.10 & 98.17 \\
\hline Tertiary education & 2 & 1.83 & 1.83 & 100.0 \\
\hline Total & 109 & 100.0 & 100.0 & \\
\hline
\end{tabular}

Source: Field Survey Data, 2014.

Table 4 which indicates the educational status of the maize farmers interviewed showed that $47 \%$ of the total respondent has no form of formal education. However, the majority $(29.0 \%)$ of the household heads have one form of formal education, and this indicates a meaningful farmers' output in the study area. 


\subsubsection{Distribution of Farmers' Categories based on their Irrigation Schemes}

The use of irrigation is a reflection of the role or impact which the education element plays in technology adoption (Cremades, Wang and Morris, 2014). This is the reason why data on the categories of irrigation used by maize farmers were collected. Results of this distribution are seen in Table 6.

Table 6: Distribution of respondents according to the irrigation schemes

\begin{tabular}{|l|l|l|l|c|}
\hline \multicolumn{1}{|c|}{ Categories of Farmers } & Frequency & Percent & $\begin{array}{c}\text { Valid } \\
\text { Percent }\end{array}$ & $\begin{array}{c}\text { Cumulative } \\
\text { Percent }\end{array}$ \\
\hline Farmers with irrigation scheme & 83 & 76.15 & 76.15 & 76.15 \\
\hline Homestead gardeners & 26 & 23.85 & 23.85 & 100.0 \\
\hline Total & 109 & 100.0 & 100.0 & \\
\hline
\end{tabular}

Source: Field Survey Data, 2014

Table 6, indicates the farmer category interviewed, and observed that more farmers who are smallholder irrigators supersede the homestead food gardeners; this is so because the irrigation scheme is available thereby showing a functional irrigation scheme in the study area. Agricultural practices which embrace user-friendly technology gets better productivity. However, irrigation has been a long year breakthrough for agriculture as the respondents in the study area embraced the maize irrigation technology with $76 \%$, while $24 \%$ of the remaining farmer practices homestead maize gardening.

\subsubsection{Distribution of Respondents based on the Number of Years Spent in Maize Farming}

Number of years which is an important determinant in efficient farming practice is synonymous to farming experience (Fan, 2009). Based on this, data was collected on the number of years the farmers spent in maize farming, and the results presented in Table 7.

Table 7: Distribution of the respondents according to the number of years spent in maize farming

\begin{tabular}{|l|l|l|l|}
\hline Number of years & Frequency & Percentage & Cum. Percentage \\
\hline $1-2$ & 17 & 18.5 & 18.5 \\
\hline $3-5$ & 11 & 13.5 & 32.0 \\
\hline $6-8$ & 19 & 21 & 53.0 \\
\hline $9-11$ & 46 & 33 & 86 \\
\hline $11-$ Above & 16 & 14.0 & 100 \\
\hline Total & 109 & 100 & \\
\hline
\end{tabular}

Source: Field Survey Data, 2014

Table 7 indicated that the number of years spent in maize farming is an important factor as it relates to the farmers' experience, and will in turn reflect the effectiveness of an agro- enterprise in order to yield a reasonable output. The result further revealed that majority (33\%) of maize farmers spent between 9 and 11 years in the farming, thereby implying that most of the maize farmers are homestead food gardeners and smallholders. 


\subsubsection{Distribution of Household heads based on their Primary Occupation}

Primary occupation is the occupation in which households spend $75 \%$ and above of their time, and from which they earn a greater proportion of their income (Echebiri, 2001). This was the reason why data was collected on the primary occupation of maize farmers and the results of the distribution is presented in Table 8.

Table 8: Distribution of respondents according to primary occupation

\begin{tabular}{|l|l|l|l|l|}
\hline Occupation & Frequency & \multicolumn{1}{|c|}{ Percent } & Valid Percent & Cum. Percent \\
\hline Farming & 97 & 89.00 & 89.00 & 89.00 \\
\hline Trading & 1 & 0.92 & 0.92 & 89.92 \\
\hline Casual Worker & 5 & 4.58 & 4.58 & 94.5 \\
\hline Civil Servant & 4 & 3.67 & 3.67 & 98.17 \\
\hline Student & 2 & 1.83 & 1.83 & 100.0 \\
\hline Total & 109 & 100.0 & 100.0 & \\
\hline
\end{tabular}

Source: Field Survey Data, 2014

Table 8 shows that about $89 \%$ of both the homestead gardeners and smallholder farmers considered maize farming as their primary occupation in Qamata and Tyefu, respectively. This gave a negative signal as it indicated a high level of unemployment in the area.

\subsubsection{Distribution of Household Heads according to their Land Acquisition}

In terms of farming enterprise, land acquisition is referred to as the process by which the government of a community or land or an authority acquires a portion of land for various infrastructure and economic growth initiatives irrespective of the controversies arising with claims of land owners. However, in this study, the importance of who sets the rules cannot be over emphasized. In other words, data was collected based on who sets the rules on land acquisition. Therefore, the results of the distribution are presented in Table 9.

Table 9: Distribution of respondents according to set rules regarding land acquisition

\begin{tabular}{|l|l|l|l|l|}
\hline Rules of Land Acquisition & Frequency & Percent & Valid Percent & Cum. Percent \\
\hline Traditional/Community Leadership & 52 & 47.71 & 47.71 & 47.71 \\
\hline Government & 15 & 13.76 & 13.76 & 61.47 \\
\hline Both & 42 & 38.53 & 38.53 & 100.0 \\
\hline Total & 109 & 100.0 & 100.0 & \\
\hline
\end{tabular}

Source: Field Survey Data, 2014

Table 9 gives a clear picture that the traditional chief set the rules and regulations with regards to land acquisition with $48 \%$, followed strictly is the government (14\%) and chiefs, and indication that both (42\%) can approve the rules that govern the acquisition of land in the area.

\subsection{Profitability Status of Smallholder Maize Enterprises}

There is an indication that smallholder maize farmer irrigators concentrate more on maize production than the homestead gardeners. From the results, the smallholder farmer irrigators generated significantly higher yield, total revenues and gross margins more than the homestead 
gardeners at a 5\%,10\% and 5\% levels, respectively. However, homestead maize gardeners spent more money in purchase of inputs and this may have contributed to their low gross margins (R254.655). Smallholder-farmer irrigators incur less input costs probably because they purchase inputs collectively, thereby reducing the unit costs. More so, smallholder-farmer irrigators have higher chances of benefiting from price discounts and transport offer by input suppliers than the homestead gardeners. However, this may be due to the smallholder-farmer irrigators having more access to reliable irrigation water supply and modernized irrigation systems compared to the homestead gardeners who have less access to irrigation water and rely mainly on traditional irrigation methods. In South Africa, the potential grain yields that can be obtained under irrigation maize farming could range from 7 - 12 tons/ha (Fanadzo et al., 2009). This however, indicates that maize yields for both smallholder irrigators and homestead gardeners are far below the expected yields. This therefore, suggests that smallholder maize irrigators are sub-optimally utilizing irrigation schemes. The low yields may be attributed to low fertilizer, pesticides and herbicides applications, among others. Furthermore, the low use of these agro-chemicals may be due to lack of investment capital to purchase these inputs. (Table 10)

Table 10: Profitability of smallholder maize enterprise

\begin{tabular}{|l|l|l|l|l|l|}
\hline Variables & Description & $\begin{array}{l}\text { Smallholder } \\
\text { Irrigators } \\
(n=70)\end{array}$ & $\begin{array}{l}\text { Homestead } \\
\text { Gardeners } \\
(n=39)\end{array}$ & $\begin{array}{l}\text { Overall } \\
\text { Sample } \\
(n=109)\end{array}$ & T-Value \\
\hline & & Mean & Mean & Mean & \\
\hline Yields & $\mathrm{Kg} / \mathrm{ha}$ & $\begin{array}{l}2199.59 \\
(2967.64)\end{array}$ & $\begin{array}{l}1468.497 \\
(1488.9)\end{array}$ & $\begin{array}{l}1834.04 \\
(2228.27)\end{array}$ & $2.061^{* *}$ \\
\hline Total revenue & Rands/ha & $\begin{array}{l}3469.89 \\
(6560.57)\end{array}$ & $\begin{array}{l}2141.48 \\
(2900.1)\end{array}$ & $\begin{array}{l}2805.69 \\
(4730.34)\end{array}$ & $1.765^{*}$ \\
\hline $\begin{array}{l}\text { Total production } \\
\text { cost }\end{array}$ & Rands/ha & $\begin{array}{l}1448.68 \\
(2280.22)\end{array}$ & $\begin{array}{l}1869.30 \\
(2803.02)\end{array}$ & $\begin{array}{l}1658.99 \\
(2541.62)\end{array}$ & -0.995 \\
\hline Gross margins & Rands/ha & $\begin{array}{l}2021.210 \\
(6035.331)\end{array}$ & $\begin{array}{l}254.655 \\
(3012.671)\end{array}$ & $\begin{array}{l}1137.932 \\
(4524.00)\end{array}$ & $2.444^{* *}$ \\
\hline
\end{tabular}

Note: SPSS Version 11 was used (where $* * *, * *$, and $*$ indicated the levels of significance at $1 \%, 5 \%$ and $10 \%)$.

Source: Computed from Field Survey Data, 2014

\section{CONCLUSION}

Smallholder irrigation and agriculture assumes a prominent role in South Africa, and has been acknowledged as a major source of livelihood for the rural poor households in the study area despite its low and declining performance in terms of productivity. Due to its important role, several efforts have been made to save its feeble performance in the face of ever increasing food insecurity, high level of unemployment and unprecedented wide spread of poverty as observed at Qamata and Tyefu irrigation schemes and other rural communities in South Africa. In spite of all the government intervention and efforts aimed at reviving the pathetic situation, the area is grappling a lot with lack of enthusiasm coupled with low entrepreneurial spirit which is needful for transformation of subsistence agriculture to commercially oriented irrigation farming. Moreover, homestead gardeners spent more money in purchase of inputs and this may have contributed to their low gross margins. On the other hand, smallholder-farmer irrigators who incur less input costs have higher chances of benefiting from price discounts and transport 
offer by input suppliers than the homestead gardeners. This results in smallholder farmer irrigators wielding more profits, thereby creating more income and wealth which is pivotal in the improvement of farmers' livelihoods.

\section{IMPLICATIONS FOR AGRICULTURAL EXTENSION}

There is need for improvement of the living conditions of the smallholder irrigated maize farmers which will in turn improve the socio-economic status as well as the income status of the maize farmers. Therefore, it is instructive that farmers are encouraged to allocate more land and other agro-inputs to maize production for increased household incomes. Furthermore, farmers need a lot of competence to handle the planting, harvesting and selling of maize, since they are the main staple food in the study area. Thus, an efficient food production and food security must be enhanced through the policies for improving access to productive resources such as land, revitalization of irrigation schemes, input subsidies financial related programme, and tractor acquisition.

\section{ACKNOWLEDGEMENTS}

The authors wish to express their appreciation to the Water Research Commission (WRC) and Govan Mbeki Research Development Centre (GMRDC) for the funding aid and logistics assistance provided in the course of carrying out the study.

\section{REFERENCES}

AGBUGBA, I.K. \& ELIJAH, S.T. 2017. Yam Production practices and Climate Change in Cross State, Nigeria, Delta Agriculturists, 9 (2/3), 25-41.

AGBUGBA, I.K. \& SHELABY, A. 2018. Marketing Analysis of Selected Vegetables in Port Harcourt Metropolis Rivers State, Nigeria, IOSR-Journal of Agriculture and Veterinary Science (IOSR-JAVS), 11(2), 26-34.

AGBUGBA, I.K. \& THOMPSON, D. 2015. Economic Analysis of Tropical Leafy Vegetables in South-East Nigeria: The Case of Rural Women Farmers, American Journal of Agricultural Sciences, 2 (2), 34-41.

AGRA. 2017. Towards Africa's Agricultural Transformation, Annual Report 2017, Alliance for a Green Revolution in Africa, Nairobi, Kenya.

AGRISA. 2017. Agri-Development Solutions and Landbouweekblad, Land Audit: A Transactions Approach, Agriculture South Africa.

ANI, S.O. \& AGBUGBA, I.K. (2017). Economics of Marketing of Cassava Derivatives (Flour, Garri and Chips) in Uzo-Uwani Local Government Area, Enugu State, Delta Agriculturists, 9(1), 46-54.

BEINART, W. 2018. South Africa: Rethinking Agriculture in South Africa - Constraints and Opportunities. Accessed from http://allafrica.com/stories/201801030476.html on 21/05/2018.

BRAND SOUTH AFRICA. 2017. The nine provinces of South Africa, Brand South Africa, Official custodian of South Africa's nation brand, 1 June 2017. Available from https://www.brandsouthafrica.com/tourism-south-africa/geography/provinces-ofsouth-africa

CHRISTIAN, M. 2017. Impact Analysis of Smallholder Irrigation Schemes on THE choice of rural livelihood strategy and household food security and household food security in 
Eastern Cape Province, Unpublished PhD Thesis, Department of Agricultural Economics and Extension, University of Fort Hare, Alice, South Africa.

COUSINS, B. 2016. 'Employment in informal-sector agriculture', circulated, in: Fourie F and Skinner F (eds). Informal Sector Employment (ISEP).

CREMADES, R. WANG, J. \& MORRIS, J. 2014. Policy support, economic incentives and the adoption of irrigation technology in China. Earth Syst. Dynam. Discuss, 5: 1543-1570. Accessed from www.earth-syst-dynam-discuss.net/5/1543/2014/doi:10.5194/ esdd-51543-2014.

DAFF. 2018. Trends in the Agricultural Sector, Department of Agriculture, Forestry and Fisheries, Pretoria, South Africa.

DEPARTMENT FOR INTERNATIONAL DEVELOPMENT. 2015. Growth building jobs and prosperity in developing countries. Accessed from http://www.oecd.org/derec/unitedkingdom/40700 982.pdf on 14/02/2015.

EASTERN CAPE DEPARTMENT OF RURAL DEVELOPMENT AND AGRARIAN REFORM. 2011.Strategic Plan 2010/11-2014/15 (updated 2011/12); Towards Vibrant, Equitable \& Sustainable Rural Communities \& Food Security.

ECHEBIRI, R.N. (2001). An Analysis of the Influence of Socio-Economic Variables on Household Income, Consumption Expenditure and Savings in Rural Southeastern Nigeria. PhD. Thesis, Unpublished. Nsukka: University of Nigeria Nsukka.

EKPA, D., OYEKALE. A.S. \& OLADELE, O.I. 2017. Evaluation of Factors Influencing Indicators of Climate Smart Agricultural Practice on Crop in North-West Nigeria, World Journal of Agricultural Research, 5(5),273-278. Accessed from http://pubs.sciepub.com/wjar/5/5/4 on 21/05/2018.

EZIHE, J.A.C., AGBUGBA, I.K. \& IDANG, C. 2017. Effect of Climatic Change and Variability on Groundnut (Arachis hypogea, L.) Production in Nigeria, Bulgarian Journal of Agricultural Science, (BJAS), 23 (6), 906-914.

HAGOS, A. \& GETA, E. 2016. Review on smallholders' agriculture commercialization in Ethiopia: What are the driving factors to focus on? Journal of Development and Agricultural Economics, 8(4), 65-76.

HARDAKER, J.B., HUIRNE, R.B.M., ANDERSON, J.R. \& LIEN, G. 2015. Coping with Risk in Agriculture, Applied Decision Analysis. CABI.

HEMMING, M. 2016. Scoping report for the proposed exploration right application for petroleum on various farms in the Magisterial Districts of Matatiele and Mt Fletcher, Eastern Cape, Draft for Public Review, Project: 723.18034.00005 S, Report No. 1.1, Rhino Oil and Gas Exploration South Africa (Pty) Ltd.

IBEAWUCHI, I.I., OKOLI, N.A., ALAGBA, R.A., OFOR, M.O., EMMA-OKAFOR, L.C., PETER-ONOH, C.A. \& OBIEFUNA, J.C. 2015. Fruit and Vegetable Crop Production in Nigeria: The gains, challenges and the way forward, Journal of Biology, Agriculture and Healthcare, 5(2), 194-208.

IYENE, S. 2017. Marketing of Selected Bread Enterprises in Port Harcourt Metropolis of Rivers State, Unpublished PG Diploma Dissertation, Department of Agricultural and Applied Economics, Rivers State University, Port Harcourt.

KOSTANDINI, G., LA ROVERE, R. \& Zhe, G. 2015. Ex-ante welfare analysis of technological change: the case of nitrogen efficient maize for African soils. Canadian Journal of Agricultural Economics (DOI: 10.1111/cjag.12067).

MACAULEY, H. 2015. Cereal Crops: Rice, Maize, Millet, Sorghum, Wheat; Feeding Africa, Background paper, An action plan for African Agricultural transformation, United Nations Economic Commission for Africa, Dakar, Senegal. 
MADZIVHANDILA, T., SIBANDA, S., YAMDJEU, A.W., MOALOSI, K. \& GWELO, F.A. 2017. Achieving Food Security and Nutrition, Chapter 10; in Africa Agriculture Status Report 2016. Progress towards Agricultural Transformation in Africa, AGRA.

MAP OF THE WORLD. 2014. South Africa Longitude and Latitude Map. Updated 05/08/2014. Accessed from www.mapsofworld.com/latlong/south-africa-lat-long.html on $18 / 02 / 15$.

MDODA, L. 2017. Market participation and value chain integration among smallholder homestead and irrigated Crop farmers in the Eastern Cape Province of South Africa, Unpublished $\mathrm{PhD}$ Thesis, Department of Agricultural Economics and Extension, University of Fort Hare, Alice, South Africa.

MUZANGWA, L., MNKENI, P.N.S. \& CHIDUZA, C. 2017. Assessment of Conservation Agriculture Practices by Smallholder Farmers in the Eastern Cape Province of South Africa. Agronomy, 7, 46.

NASEER, O., AL, M. \& MASSOMEH, H. 2016, "Integration of Emerging Stock Markets with Global Stock Markets," Research in International Business and Finance, 36, 1 -12.

NDORNE, B. 2018. Marketing Analysis of Maize in Bori Urban of Khana Local Government Area, Rivers State, Unpublished PG Diploma Dissertation, Department of Agricultural and Applied Economics, Rivers State University, Port Harcourt.

OBI, A. \& POTE, P. 2012. Technical constraints to market access for crop and livestock farmers in Nkonkobe Municipality, the Eastern Cape Province, In: A. Obi, H. D. van Schalkwyk, J. A. Groenewald, G.C.G. Fraser and Aad Van Tilburg (eds), Unlocking markets to smallholders: Lessons from South Africa. Mansholt Publication series-volume 10 Wageningen.

ODUNITAN-WAYAS, F.A/, KOLANISI. U., CHIMONYO, M. \& SIWELA, M. 2016. Effect of provitamin a biofortified maize inclusion on quality of meat from indigenous chickens. J. Appl. Poult. Res., 25, 581-590.

OFFIAH, E.O. 2015. Sustainability of maize-based production system in Anambra State Nigeria, M.Sc. Dissertation in the Department of Agricultural Economics, University of Nigeria, Nsukka Nigeria.

SACCG. 2017. South Africa - Agricultural Sector, South Africa Country Commercial Guide. Accessed from https://www.export.gov/article?id=South-Africa-agriculturalequipment on 21/05/2018.

SIBANDA, M., MUSHUNJE, A. \& MUTENGWA, C.S. 2016. An evaluation on the profitability of growing improved maize open pollinated varieties in the Eastern Cape Province, South Africa, Journal of Development and Agricultural Economics, 8 (1), 113.

SINGH, V.K., DWIVEDI, B.S., SINGH, S.K., MAJUMDAR, K., JAT, M.L., MISHRA, R.P. \& RANI, M. 2016. Soil physical properties, yield trends and economics after five years of conservation agriculture based rice-maize system in north-western India. Soil Tillage Res. 155, 133-148.

SINYOLO, S., MUDHARA, M. \& WALE, E. (2014). The impact of smallholder irrigation on household welfare: The case of Tugela Ferry irrigation scheme in KwaZulu-Natal, South Africa; Water South Africa, 40, 1.

SLAMET, A,S,, NAKAYASU, A. \& ICHIKAWA, M. 2017. Small-Scale Vegetable Farmers' Participation in Modern Retail Market Channels in Indonesia: The Determinants of the Effects on Their Income, Agriculture, 7 (11), 2-16. 
SOUTH AFRICAN GOVERNMENT. 2015. Agriculture. Accessed from http://www.gov.za/aboutsa/ agriculture on 20/02/2015.

VON LOEPER, W., MUSANGO, J., BRENT, A. \& DRIMIE, S. 2016. Analysing challenges facing smallholder farmers and conservation agriculture in South Africa: A system dynamics approach. South African Journal of Economic and Management Sciences, 19(5), 747.

WIGGINS, S. \& KEATS, S. 2013. Leaping and Learning: Linking Smallholders to Markets, Agriculture for Impact, Imperial College London. Accessed from http://www.odi.org/sites/odi.org.uk/files/odi-assets/publications-opinionfiles/8401.pdf on 21/11/2017.

ZUMA, M.K., KOLANISI, U. \& MODI, A.T. 2018. The Potential of Integrating Pro-Vitamin A-Biofortified Maize in Smallholder Farming Systems to Reduce Malnourishment in South Africa, Int. J. Environmental Res. Public Health, 15(4), 805 
S. Afr. J. Agric. Ext.

Vol. 48 No.2, 2020: 50 - 63

http://dx.doi.org/10.17159/2413-3221/2020/v48n2a537
Agbugba, Christian \& Obi

(License: CC BY 4.0) 